\title{
Peran Kegiatan Ekstrakurikuler Pramuka Dalam Pembentukan Karakter Peserta Didik di SD Kemala Bhayangkari 1 Surabaya
}

\author{
Lu'luun Nasifah $^{1}$, Syamsul Ghufron ${ }^{2}$, Mohammad Taufiq ${ }^{3}$, Akhwani $^{4}$ \\ Program Studi PGSD Universitas Nahdlatul Ulama Surabaya ${ }^{1234}$ \\ sifanasifah45@gamil.com ${ }^{1}$, syamsulghufron@unusa.ac.id ${ }^{2}$ \\ 'mtaufiq79@unusa.ac.id ${ }^{3}$, Akhwani@unusa.ac.id ${ }^{4}$
}

\begin{abstract}
Abstrak
Penelitian ini mengenai peran kegiatan ekstrakurikuler pramuka dalam pembentukan karakter peserta didik. Penelitian ini dilaksanakan pada bulan April 2020 sampai dengan Juni 2020. Penelitian ini bertujuan untuk mendeskripsikan kegiatan ekstrakurikuler pramuka di SD Kemala Bhayangakri 1 Surabaya, mendeskripsikan karakter yang terbentuk, mendeskripsikan kendala dalam proses pembentukan dan mendeskripsikan solusi dalam mengatasi kendala. Metode penelitian yang digunakan adalah penelitian kualitatif. Subjek penelitian ini adalah pembina pramuka golongan penggalang yakni dari kelas 3, 4, 5, dan 6. Teknik pengumpulan data ini menggunakan observasi dan wawancara Teknik analisis data yang digunakan adalah reduksi data, penyajian data, verifikasi dan penyimpulan. Instrumen penelitian ini menggunakan pedoman wawancara dan pedoman observasi. Hasil penelitian menunjukkan bahwa karakter yang sudah terbentuk melalui kegiatan ekstrakurikuler pramuka di SD Kemala Bhayangkari 1 Surabaya adalah karakter disiplin dan mandiri, dan kegiatan-kegiatan yang telah dilaksanakan adalah kegiatan tali-menali dan baris-berbaris. Kesimpulannya bahwa indikator dari karakter disiplin adalah hadir tepat waktu, mematuhi aturan, menepati jadwal pelajaran apabila siswa tersebut memiliki jadwal pelajaran. Kemudian indikator dari karakter mandiri adalah tidak bergantung pada orang lain, terlibat aktif dalam semua pembelajaran di kelas, bersedia mengerjakan tugas individual dan kelompok di depan kelas.
\end{abstract}

Kata kunci: ekstrakurikuler pramuka, karakter disiplin, karakter mandiri 


\section{PENDAHULUAN}

Karakter menurut pusat bahasa depdiknas adalah "bawaan, hati, jiwa, kepribadian, karakter dan akhlak mulia, perilaku, personalitas, sifat, tabiat, temperamen, watak. Dengan kata lain karakter mengacu kepada kepribadian seseorang yang membedakan seseorang dengan yang lain. Ghozali juga mengemukakan bahwa karakter lebih dekat dengan akhlaq, yaitu spontanitas manusia dalam bersikap atau melakukan perbuatan yang telah menyatu dalam diri manusia sehingga ketika muncul tidak perlu dipikirkan lagi (Gunawan, 2014:3).

Pramuka (Praja Muda Karana) yang mempunyai arti jiwa muda yang suka berkarya adalah proses pendidikan yang menyenangkan bagi anak muda. Di bawah tanggung jawab anggota dewasa, yang dilakukan di luar lingkungan sekolah dan keluarga, dengan tujuan, prinsip dasar dan metode pendidikan tertentu. (Permendikbud No.63 Tahun 2014). Pada dasarnya kegiatan kepramukaan memiliki tujuan untuk melatih generasi muda agar memaksimalkan setiap potensi yang ada dalam dirinya. Baik intelektual, spiritual, dan fisik. Tujuan tersebut dapat dijabarkan sebagai pembentuk karakter/kepribadian dan akhlak mulia bagi generasi muda. Pramuka adalah warga negara Indonesia yang aktif dalam pendidikan kepramukaan serta mengamalkan Satya Pramuka dan Darma Pramuka. Kepramukaan adalah segala aspek yang berkaitan dengan pramuka. Pendidikan Kepramukaan adalah proses pembentukan kepribadian, kecakapan hidup, dan akhlak mulia pramuka melalui penghayatan dan pengamalan nilai-nilai kepramukaan.

Pendidikan karakter bertujuan untuk membentuk manusia Indonesia yang bermoral, membentuk manusia Indonesia yang cerdas dan rasional, membentuk manusia yang inovatif, suka bekerja keras, optimis, percaya, dan berjiwa patriot. Dengan demikian, pendidikan yang sangat dibutuhkan saat ini adalah pendidikan yang dapat mengintegrasikan pendidikan karakter dengan pendidikan yang dapat mengoptimalkan perkembangan seluruh dimensi anak baik dari ranah kognitif, fisik, sosialemosi, kreativitas, dan spiritual harus seimbang.

Pramuka sebagai salah satu kegiatan ekstrakulikuler di sekolah sangat relavan sebagai wadah penanaman nilai karakter. Nilai karakter yang dapat dikembangkan melalui kegiatan kepramukaan adalah sebagai berikut: religius, jujur, toleransi, 
disiplin, kerja keras, kreatif, mandiri demokratis, rasa ingin tau, semangat kebangsaan, cinta tanah air, menghargai prestasi, bersahabat atau komunikatif, cinta damai, gemar membaca, peduli lingkungan, peduli sosial, dan tanggung jawab. Ekstrakurikuler wajib disekolah salah satunya adalah pramuka yang diatur dalam peraturan Menteri Pendidikan dan Kebudayaan Republik Indonesia Nomor 63 Tahun 2014 Tentang Pendidikan Kepramukaan sebagai Kegiatan Ekstrakurikuler Wajib pada Pendidikan Dasar dan Pendidikan Menengah.

Menurut Aristoteles Heri Gunawan (2012:23), bahwa “ karakter itu erat hubungannya dengan kebiasaan yang kerap dimanifestasikan dalam tingkat laku“, Karakter merupakan cerminan diri manusia terkait tentang tabiat seseorang dalam bertingkah laku yang menjadi kebiasaan dalam kesehariannya.

Thomas Lickona dalam Heri Gunawan (2012:23), menyebutkan bahwa "pendidikan untuk membentuk kepribadian seseorang melalui pendidikan budi pekerti, yang hasilnya terlihat dalam tindakan nyata seseorang, yaitu tingkah laku yang baik, jujur bertanggung jawab, menghormati hak orang lain, kerja keras, dan sebagainya. Kegiatan pramuka menurut H. Soemarno dalam Merli (2011:25), karakter merupakan nilai-nilai yang terpatri dalam diri kita melalui pendidikan, pengalaman, percobaan, pengorbanan, dan pengaruh lingkungan.

Tujuan penelitian ini adalah untuk mendeskripsikan peran kegiatan ekstrakurikuler pramuka dalam pembentukan karakter peserta didik di SD Kemala Bhayangkari 1 Surabaya.

\section{METODE PENELITIAN}

Penelitian ini menggunakan pendekatan kualitatif yang bersifat deskriptif. Menurut Arifin (2012:140), penelitian kualitatif adalah suatu proses penelitian yang dilakukan secara wajar dan natural sesuai dengan kondisi objektif di lapangan tanpa adanya manipulasi, serta jenis data yang dikumpulkan terutama data kualitatif. Sebelum peneliti mengadakan penelitian, peneliti membuat susunan pedoman wawancara dan pedoman observasi, sebelum melakukan wawancara, peneliti melakukan observasi terlebih dahulu untuk pengamatan terhadap lingkungan dan kegiatan sekolah sekitar. 
Sumber data dalam penelitian ini adalah pembina pramuka dan siswa di SD Kemala Bhayangkari 1 Surabaya. Pembina pramuka terdiri atas 2 orang Pembina, adapun siswa-siswinya terdiri atas siswa-siswi kelas 3, kelas 4, dan kelas 5 yang berjumlah 72 siswa. dengan rincian siswa kelas 3 berjumlah 20 siswa, 11 siswa lakilaki dan 9 siswi perempuan, kelas 4 berjumlah 22 siswa, 15 siswa laki-laki dan 7 siswi perempuan, kelas 5 berjumlah 30 siswa, 11 siswa laki-laki dan 19 siswi perempuan.

Arifin (2012:54) menyatakan bahwa pendekatan kualitatif deskriptif adalah penelitian yang digunakan untuk mendeskripsikan dan menjawab persoalanpersoalan suatu fenomena atau peristiwa yang terjadi saat ini, baik tentang fenomena dalam variabel tunggal maupun korelasi dan atau perbandingan berbagai variabel. Artinya, variabel yang diteliti bisa tunggal (satu variabel) bisa juga lebih dari satu variabel. Penelitian deskriptif berusaha mendeskripsikan suatu peristiwa atau kejadian yang menjadi pusat perhatian tanpa memberikan perlakuan khusus terhadap peristiwa tersebut.

Tujuan penelitian deskriptif, yakni untuk menjelaskan secara sistematis, faktual, dan akurat mengenai fakta-fakta dan sifat-sifat populasi atau daerah tertentu. Tujuan utamanya ialah untuk mengamati dan memahami perilaku seseorang atau kelompok orang dalam situasi tertentu. Peneliti bisa mengamati sekelompok peserta didik ketika bermain dengan teman-temannya untuk memahami perilaku interaksi sosial mereka (Arifin, 2012: 153).

Penelitian ini dilakukan di SD Kemala Bhayangkari 1 Surabaya Jl. Ahmad Yani No. 30-32, Ketintang, Kec. Gayungan Surabaya. Pengambilan data awal dilakukan pada tanggal 29 November 2019. Sedangkan penelitian ini dilakukan pada semester genap bulan april 2020.

Penelitian ini menggunakan teknik pengumpulan data yaitu hasil observasi dan wawancara. Obervasi menurut Arifin (2012: 230) menjelaskan bahwa observasi merupakan suatu proses yang alami, dimana kita semua sering melakukannya, baik secara sadar maupun tidak sadar dalam kehidupan sehari-hari. Teknik observasi ini digunakan untuk mengumpulkan data hasil pengamatan lingkungan sekolah, keadaan lapangan, dan proses selama kegiatan berlangsung dengan cara melihat dan mengamati keadaan lingkungan di sekolah serta proses kegiatan belajar mengajar. 
Wawancara merupakan teknik pengumpulan data yang dilakukan melalui percakapan dan tanya-jawab, baik langsung maupun tidak langsung dengan responden untuk mencapai tujuan tertentu. Pengertian wawancara langsung adalah wawancara yang dilakukan secara langsung antara pewawancara (interviewer) dan orang yang diwawancarai (interviewee) tanpa melalui perantara. Tujuan wawancara adalah untuk memperoleh informasi secara langsung, menyelami dunia perasaan dan pikiran seseorang.

Menurut Arifin (2012: 234), untuk menyusun pedoman wawancara (interview guide), dapat diikuti langkah-langkah sebagai berikut: merumuskan tujuan wawancara, membuat kisi-kisi atau layout dan pedoman wawancara, menyusun pertanyaan sesuai dengan data yang diperlukan dan bentuk pertanyaan yang diinginkan.

Menurut Arifin (2012:171), dalam penelitian kualitatif analisis data merupakan upaya berlanjut, berulang dan sistematis. Analisis data dilakukan dalam dua tahap, yaitu pada saat pengumpulan data dan setelah data terkumpul. Dalam penelitian kualitatif, analisis data dilakukan dengan memperhatikan hubungan antara konsep abstrak dan bagian data. Tekniknya adalah mendeskripsikan dan mengeksplanasikan peristiwa.

Teknik analisis data yang digunakan dalam penelitian ini adalah reduksi data, penyajian data, verifikasi. Miles dan Huberman (1992:16) mengemukakan bahwa tahap kegiatan dalam menganalisis data kualitatif, yaitu "reduksi data, penyajian data, dan menarik simpulan/verifikasi”. Reduksi data merupakan langkah awal dalam mengalisis data. Tujuannya adalah untuk memudahkan pemahaman terhadap data yang diperoleh. Pada tahap ini, peneliti memilih data mana yang relavan dan kurang relavan dengan tujuan dan masalah penelitian, kemudian meringkas, memberi kode, selanjutnya mengelompokkan (mengorganisir) sesuai dengan tematema yang ada.

Reduksi data merupakan bagian dari analisis, reduksi data merupakan suatu bentuk analisis yang menajamkan, menggolongkan, mengarahkan, membuang yang tidak perlu, dan mengorganisasi data dengan cara sedemikian rupa hingga kesimpulan-kesimpulan finalnya dapat ditarik dan diverifikasi. 
Penyajian data, Miles dan Huberman membatasi suatu penyajian sebagai sekumpulan informasi tersusun yang memberi kemungkinan adanya penarikan kesimpulan dan pengambilan tindakan. Data dalam penelitian ini disajikan dengan sistematika berikut: (1) paparan terkait dengan teori yang diambil dari rincian rumusan masalah, (2) data terseleksi dari hasil observasi dan wawancara, (3) interpretesi yang dibuat peneliti.

Verifikasi data adalah pembentukan kebenaran teori, fakta, atas data yang dikumpulkan untuk diolah dan dianalisi agar bisa diuji secara hipoteis. Hipotesis tersebut kemudian diuji menggunakan beberapa fakta empiric yang dapat dipertanggung jawabkan jika menggunakan prosedur yang sesuai. Verifikasi memiliki prinsip bahwa setiap proporsi memiliki makna, jika proporsi tersebut bisa diuji dan bisa diverifikasi dengan pengamatan. Verifikasi dan penyimpulan dilakukan dengan cara membaca data berulang-ulang, minta sumber data untuk mengoreksinya, selanjutnya dirumuskan dalam bentuk simpulan penelitian.

\section{HASIL DAN PEMBAHASAN}

\section{Pedoman observasi}

Tabel 1. Pedoman Observasi

\begin{tabular}{|c|c|c|}
\hline No. & Aspek & Hasil Pengamatan \\
\hline 1 & Alamat/lokasi sekolah & $\begin{array}{l}\text { Sekolah Dasar Kemala Bhayangkari } 1 \\
\text { Surabaya di JL. Jenderal A. Yani 30-32 }\end{array}$ \\
\hline 2 & $\begin{array}{l}\text { Kondisi lingkungan/lapangan } \\
\text { sekolah }\end{array}$ & $\begin{array}{l}\text { Kurang strategis, namun latihan masih } \\
\text { bisa tetap berjalan }\end{array}$ \\
\hline 3 & $\begin{array}{l}\text { Jumlah siswa dan Pembina } \\
\text { pramuka }\end{array}$ & $\begin{array}{l}\text { Jumlah siswa } 80 \text { anak dan } 3 \text { orang } \\
\text { Pembina pramuka, } 1 \text { pembina siaga dan } 2 \\
\text { pembina penggalang }\end{array}$ \\
\hline 4 & $\begin{array}{l}\text { Suasana saat memulai kegiatan } \\
\text { hingga selesai kegiatan }\end{array}$ & $\begin{array}{l}\text { Kegiatan berjalan dengan baik dan } \\
\text { disiplin, siswa-siswinya mengikuti dan } \\
\text { memperhatikan pembelajaran yang } \\
\text { disampaikan oleh pembina. }\end{array}$ \\
\hline 5 & $\begin{array}{l}\text { Proses kegiatan belajar mengajar } \\
\text { di lapangan }\end{array}$ & $\begin{array}{l}\text { Kegiatan dimulai dengan baris-berbaris, } \\
\text { kemudian siswa diarahkan untuk } \\
\text { mengurus administrasi berupa absen, } \\
\text { selanjutnya adalah materi. Untuk } \\
\text { materinya yakni meliputi: pionering, } \\
\text { sandi, memasak, baris-berbaris, kerajinan } \\
\text { tangan, dan kompas. Kemudian diakhiri } \\
\text { dengan baca do'a sekaligus review-review }\end{array}$ \\
\hline
\end{tabular}




\begin{tabular}{|c|c|c|}
\hline & & kegiatan. \\
\hline 6 & $\begin{array}{l}\text { Siapa saja yang berperan dalam } \\
\text { kegiatan ekstrakurikuler pramuka }\end{array}$ & $\begin{array}{l}\text { Koordinasi kepramukaan, pembina } \\
\text { ekstrakurikuler pramuka dan siswa- } \\
\text { siswinya/anggotanya. }\end{array}$ \\
\hline 7 & Karakter apa saja yang dibentuk & $\begin{array}{l}\text { Kemandirian, kedisiplinan, kebersamaan, } \\
\text { jiwa sosial, religius. }\end{array}$ \\
\hline 8 & $\begin{array}{r}\text { Bagaimana kegiatan } \\
\text { ekstrakurikuler pramuka }\end{array}$ & 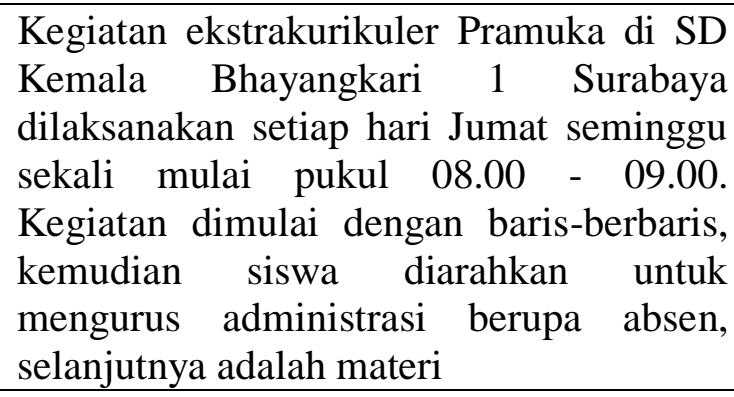 \\
\hline 9 & $\begin{array}{l}\text { Kendala yang timbul dalam } \\
\text { proses pembentukan moral }\end{array}$ & $\begin{array}{l}\text { Guru belum mampu menguasai anak- } \\
\text { anak, tempat kurang strategis, media } \\
\text { pembelajaran kurang lengkap. }\end{array}$ \\
\hline 10. & $\begin{array}{l}\text { Solusi dalam mengatasi kendala } \\
\text { tersebut }\end{array}$ & $\begin{array}{l}\text { Pembina harus tegas dan berwibawa, } \\
\text { memilih tempat yang strategis, } \\
\text { menggunakan media yang tepat. }\end{array}$ \\
\hline
\end{tabular}

Pedoman wawancara

Tabel 2. Pedoman Wawancara

\begin{tabular}{|c|c|c|}
\hline Indikator & Yang diukur & Pertanyaan wawancara \\
\hline $\begin{array}{l}\text { Disiplin: } \\
\text { perilaku yang taat } \\
\text { dan patuh pada } \\
\text { aturan, tata tertib di } \\
\text { sekolah }\end{array}$ & $\begin{array}{l}\text {-Hadir tepat waktu } \\
\text {-Mematuhi aturan } \\
\text {-Menepati jadwal } \\
\text { pelajaran. }\end{array}$ & $\begin{array}{l}\text { 1. Bagaimana mengatasi siswa yang } \\
\text { hadir tidak tepat waktu ? } \\
\text { 2. Bagaimana cara mangatasi siswa } \\
\text { yang tidak mematuhi aturan sekolah } \\
\text { ? } \\
\text { 3. Setujukah kakak dengan adanya } \\
\text { pembentukan karakter disiplin di } \\
\text { sekolah SD Kemala Bhayangkari } 1 \\
\text { Surabaya? } \\
\text { 4. Mengapa perlu adanya pendidikan } \\
\text { karakter disiplin? } \\
\text { 5. Tugas siapakah penanaman pendidikan } \\
\text { karakter disiplin?, cocokkah } \\
\text { diterapkan dilingkungan sekolah SD } \\
\text { Kemala Bhayangkari } 1 \\
\text { Surabaya? } \\
\text { 6. Bagaimana metode atau model } \\
\text { pengajaran pendidikan karakter di SD }\end{array}$ \\
\hline
\end{tabular}




\begin{tabular}{|c|c|c|}
\hline & & $\begin{array}{l}\text { Kemala Bhayangkari } 1 \\
\text { Surabaya ? } \\
\text { 7. Adakah pengaruh negative dari } \\
\text { pendidikan karakter disiplin di SD } \\
\text { Kemala Bhayangkari } 1 \text { Surabaya ? } \\
\text { 8. Dimanakah letak keberhasilan } \\
\text { pendidikan karakter disiplin itu di SD } \\
\text { Kemala Bhayangkari } 1 \\
\text { Surabaya? } \\
\text { 9. Bagaimanakah cara mengatasi karakter } \\
\text { siswa yang kurang disiplin menepati } \\
\text { jadwal. } \\
\text { 10. Bagaimana upaya mengatasi siswa } \\
\text { yang sering datang terlambat? } \\
\text { 11. Bagaimana menanamkan nilai-nilai } \\
\text { karakter disiplin ? } \\
\text { 12. Apa harapan anda dengan adanya } \\
\text { pendidikan karakter disiplin } \\
\text { dilingkungan sekolah? }\end{array}$ \\
\hline Indikator & Yang diukur & Pertanyaan wawancara \\
\hline $\begin{array}{l}\text { Mandiri: } \\
\text { perilaku tidak } \\
\text { bergantung pada } \\
\text { orang lain dan } \\
\text { mempergunakan } \\
\text { tenaga, pikiran, } \\
\text { waktu untuk } \\
\text { merealisasikan } \\
\text { harapan, mimpi, } \\
\text { dan cita-cita. }\end{array}$ & $\begin{array}{l}\text { - Tidak bergantung } \\
\text { pada orang lain } \\
\text { - Terlibat aktif } \\
\text { dalam semua } \\
\text { pembelajaran di } \\
\text { kelas. } \\
\text { - Bersedia } \\
\text { mengerjakan } \\
\text { tugas individual } \\
\text { dan kelompok di } \\
\text { depan kelas }\end{array}$ & $\begin{array}{l}\text { 1. Bagaimana cara mengatasi siswa } \\
\text { yang tidak aktif dalam pembelajaran } \\
\text { di kelas? } \\
\text { 2. Kenapa siswa tersebut tidak aktif } \\
\text { dalam pembelajaran di kelas? } \\
\text { 3. Bagaimana cara mengatasi siswa } \\
\text { supaya bisa mengerjakan tugas } \\
\text { individu atau kelompok } \\
\text { 4. Bagaima Kakak mengatasi siswa } \\
\text { yang bergantung pada orang lain? } \\
\text { 5. Apa hambatan pembelajaran di } \\
\text { dalam kelas? }\end{array}$ \\
\hline
\end{tabular}

Kegiatan Ekstrakurikuler Pramuka di Sekolah Dasar Kemala Bhayangkari 1 Surabaya yang terletak di JL. Jenderal A. Yani 30-32. Pelaksanaan pengembangan pendidikan karakter di SD Kemala Bhayangkari 1 Surabaya dalam program pendidikan karakter melaksanakan setiap hari di sekolah. Yang mana kegiatan anak selama di sekolah akan dipantau oleh guru-guru dan pembina pramuka, mulai dari siswa masuk sekolah hingga pulang sekolah. Semua kegiatan ini sudah terprogram dalam jadwal kegiatan harian siswa-siswi Sekolah Dasar Kemala Bhayangkari 1 Surabaya. Terdapat program struktur di dalam kegiatan ekstrakurikuler pramuka, pada awal kegiatan tepatnya awal tahun ajaran guru dan pembina diarahkan untuk 
membuat proposal guna proses kegiatan selama 1 tahun itu apa saja. Di situ sudah tertuang kegiatan terstruktur dan semua sudah terjadwal. Kegiatan ekstrakurikuler pramuka berjalan sesuai dengan program struktur di sekolah, untuk pelaksaan kegiatan ekstrakurikuler pramuka kegiatannya setiap hari jumat seminggu sekali mulai pukul 08.00 - 09.00 .

Jumlah siswa regu penggalang dari kelas 3, 4, 5, 6 ada 80 anak bertempat di lapangan, sedangkan siswa regu siaga kelas 1 dan 2 pembelajaran bertempat di kelas. Kegiatan awal saat akan memulai kepramukaan, yang pertama adalah baris-berbaris, dalam kegiatan ekstrakurikuler pramuka juga ada banyak manfaat dan tujuannya, karena dari kegiatan ekstrakurikuler pramuka sendiri itu menyentuh kegiatan anakanak jadi sudah pasti bisa melatih kemandirian anak, melatih kedisplinan, melatih bersosial dengan teman-temannya. Dalam kepramukaan di SD Bhayangkari ada 3 guru pembina pramuka yaitu 1 dari pembina regu siaga kak anita firda febrianti dan 2 pembina regu penggalang Kak Aini wijayanti, S.Pd dan Kak Ikwan effendi, S.Pd.

Jenis kegiatan ekstrakurikuler pramuka di SD Kemala Bhayangkari 1 Surabaya terdiri atas kegiatan-kegiatan berikut: (1) persami, (2) lomba-lomba, (3) bakti social, (4) kegiatan religious, (5) kim-kim. Di SD Kemala Bhayangkari 1 Surabaya tidak ada jadwal rutin untuk setiap pertemuannya, kegiatan dilakukan sesuai yang ada di SKU. Namun kegiatan-kegiatan yang telah dilaksanakan adalah kegiatan tali-menali dan baris-berbaris.

Persami adalah perkemahan sabtu minggu, perkemahan yang dilaksanakan setiap hari sabtu dan minggu. Di SD Kemala Bhayangkari 1 Surabaya persami ini dilaksanakan setelah Ujian Akhir Semester atau menjelang liburan semester 1, kegiatannya dalam bentuk perkemahan sabtu dan minggu. Kegiatan ini diikuti anakanak kelas 4, 5, dan 6. Dalam kegiatan persami tersebut siswa dilatih agar menjadi siswa yang disiplin, mandiri, kompak dalam tim, dan dilatih ketangkasan.

Kalau kegiatan persami biasanya dilaksanakan setelah Ujian Akhir Semester atau menjelang liburan semester 1, jadi persami ini dilakukan satu tahun sekali. Kemudian biasanya dilaksanakan bisa di halaman sekolah juga di luar kota, kalau yang terakhir itu di luar kota di pasuruan. (Wawancara oleh kakak Pembina Pramuka Aini Wijayanti, S.Pd tanggal 09 juni 2020 pada pukul 18.35).

Lomba adalah salah satu kegiatan yang mengasah potensi kemampuan dan bakat anak. Siswa SD Kemala Bhayangkari dituntut untuk serba bisa, manfaat kegiatan perlombaan meliputi : mengasah keterampilan sosial, menumpuk jiwa persahabatan, belajar 
mengikuti aturan atau instruksi, memahami makna sportivitas, melatih kepercayaan diri, serta menumbukan rasa nasionalisme.

Kemudian kalau lomba tergantung adanya undangan yang masuk ke sekolah, kalau bhayangkari memang kurang aktif sebenarnya, kalau sekolah negeri biasanya cuma ikut lombanya itu cuma lomba-lomba wajib yang ada di kecamatan. (Wawancara oleh kakak Pembina Pramuka Aini Wijayanti, S.Pd tanggal 09 juni 2020 pada pukul 18.44).

Bakti sosial adalah salah satu kegiatan wujud dari rasa kemanusiaan antara sesama manusia. Dengan kegiatan tersebut siswa-siswi SD Kemala Bhayangkari 1 Surabaya dapat membentuk pribadi yang memiliki rasa cinta kasih, saling tolongmenolong, melatih kemandirian, melatih ketangkasan, melatih tanggung jawab, melatih jiwa sosial, serta menumbuhkan rasa moralitas yang tinggi.

kalau bakti social di SD Bhayangkari yang sudah sering dilakukan itu ketika persami. Ketika persami itu anak-anak biasanya satu regu disuruh bawa mie instan, kecap, minyak ukuran kecil, garam, gula, teh seperti itu. Kemudian satu regu itu di kemas jadi satu dibungkus kresek, terus kemudian nanti ketika penjelajahan nanti mereka sambil membagikan. . (Wawancara oleh kakak Pembina Pramuka Aini Wijayanti, S.Pd tanggal 09 juni 2020 pada pukul 18.35).

Kegiatan religious yaitu kegiatan yang mengajarkan sikap dan perilaku yang patuh dalam melaksanakan ajaran agama yang dianutnya.

Kalau kegiatan religious di ekstrakurikuler pramuka itu masuk dalam syarat kecakapan umum. (Wawancara oleh kakak Pembina Pramuka Aini Wijayanti, S.Pd tanggal 09 juni 2020 pada pukul 19.16).

Kim adalah singkatan dari kemampuan indra manusia, kim ini biasanya dilakukan di saat game kegiatan pramuka SD Kemala Bhayangkari 1 Surabaya. Kim ada variasinya yaitu ada kim melihat, kim meraba, dan kim membau, game tersebut dilakukan dengan keadaan mata yang tertutup. Tujuan kim game kim tersebut mengasah kemampuan indra manusai.

Kim di kegiatan pramuka adalah singkatan dari kemampuan indra manusia. Kegiatan kim ini mengasah kemampuan indra dari anak-anak didik. Misalkan kim melihat, kim melihat itu berarti contohnya begini, adik-adik diperlihatkan sepuluh benda secara singkat, sepuluh macam benda misalnya, kemudian setelah di perlihatkan kemudian benda itu disembunyikan lalu adik-adik disuruh menulis benda apa yang dilihat, nah itu namanya kim melihat. (Wawancara oleh kakak Pembina Pramuka Aini Wijayanti, S.Pd tanggal 09 juni 2020 pada pukul 19.23). 
Dari kegiatan ekstrakurikuler pramuka tentunya memiliki banyak sekali tujuan dan manfaat tersendiri, salah satunya adalah memiliki tujuan untuk pembentukan karakter. Karakter yang akan dibentuk meliputi kemandirian dan kedisiplinan.

Kemandirian adalah sikap dan perilaku yang tidak menggantungkan diri kepada orang lain dalam menyelesaikan berbagai tugas maupun persoalan. Anakanak Di SD Kemala Bhayangkari 1 Surabaya dalam kegiatan pramuka belajar mengenai kebiasaan-kebiasaan hidup dalam kemandirian, yang bisa memicu pembentukan sikap kemandirian anak, misalnya belajar menemukan solusi dalam suatu problem.

Kemandirian di pramuka itu berarti dia sudah bisa melakukan sesuatu sendiri jadi tanpa bantuan orang lain, nah dia bisa melakukan contohnya biasanya kalau di pramuka siaga itu dapat menggoreng telur sendiri nah ada prakteknya itu nanti kalau di pramuka. Kemudian kalau di penggalang bisa memakai hasduk sendiri, bisa menali sepatu sendiri, kemudian bisa menyambung tongkat sendiri misalkan dua tongkat panjang biar panjang. Jadi kemandirian itu kalau dalam kegiatan pramuka berarti sudah bisa melakukan sendiri tanpa bantuan orang lain. (Wawancara oleh kakak Pembina Pramuka Aini Wijayanti, S.Pd tanggal 09 juni 2020 pada pukul 20.12).

Kedisiplinan adalah kebiasaan-kebiasaan yang mengubah sikap dan perilaku menjadi taat pada aturan, pada hukum ataupun perintah. Anak-anak di SD Bhayangkari diajarkan pembiasaan-pembiasaan disiplin, misalnya: hadir tepat waktu, siswa patuh dan taat terhadap aturan-aturan kelas dan sekolah yang sudah ditetapkan, serta tertib dalam memakai atribut sekolah atau pramuka. Hal ini sesuai dengan hasil wawancara berikut.

Kalau disiplin berarti tepat waktu kemudian sesuai dengan peraturan. Nah disiplin ini kalau dalam kegiatan pramuka contohnya tertib dalam memakai seragam lengkap, kemudian mengikuti kegiatan dengan tepat waktu, mengumpulkan tugas dengan tepat waktu, mrmatuhi peraturan. (Wawancara oleh kakak Pembina Pramuka Aini Wijayanti, S.Pd tanggal 09 juni 2020 pada pukul 20.12).

\section{SIMPULAN}

Indikator pembentukan karakternya adalah: untuk karakter disiplin, peserta didik yang taat dan patuh pada aturan, dan tata tertib di sekolah. Kemudian untuk karakter mandiri, peserta didik tidak bergantung pada orang lain dan mempergunakan tenaga, pikiran, waktu, untuk merealisasikan harapan dan mimpi. 
Kegiatan ekstrakurikuler Pramuka di SD Kemala Bhayangkari 1 Surabaya dimulai dengan baris-berbaris, kemudian siswa diarahkan untuk mengurus administrasi berupa absen, selanjutnya adalah materi.

Beberapa macam jenis kegiatan ekstrakurikuler pramuka di SD Kemala Bhayangkari 1 Surabaya terdiri atas kegiatan-kegiatan berikut: persami, lombalomba, kegiatan religius, kim-kim. Namun kegiatan yang rutin dilaksanakan adalah baris-berbaris dan tali-menali. Kegiatan ekstrakurikuler pramuka di SD Kemala Bhayangkari 1 Surabaya memiliki banyak sekali tujuan dan manfaat. Salah satunya adalah untuk pembentukan karakter, yakni karakter disiplin dan mandiri.

Saat proses kegiatan ekstrakurikuler pramuka di SD Kemala Bhayangkari tentunya saat kegiatan pembentukan karakter pasti ada kendala atau hambatan waktu mengajar. Berikut hambatan-hambatan dalam proses pembentukan karakter meliputi: (1) guru belum mampu menguasai anak-Anak, (2) tempat kurang strategis, (3) media pembelajaran kurang lengkap.

Terdapat solusi dalam mengatasi kendala kegiatan ekstrakurikuler pramuka di SD Kemala Bhayangkari 1 Surabaya yakni meliputi solusi sebagai berikut: (1) pembina harus tegas dan berwibawa, (2) memilih tempat yang strategis, (3) menggunakan media yang tepat.

\section{DAFTAR PUSTAKA}

Agustin, Mubiar. 2014. Permasalahan Belajar dan Inovasi Pembelajaran: Panduan untuk Guru, Konselor, Psikolog, Orang Tua, dan Tetangga. Bandung: PT Refika Aditama.

Aji, Herucakra. 2016. 'Pendidikan Karakter Dalam Ekstrakurikuler Pramuka di SMP Negeri 1 Yogyakarta', Jurnal Kebijakan Pendidikan Edisi 1 Vol. V Tahun 2016

Arifin, Z. 2012. Penelitian Pendidikan: Metode dan Paradigma Baru. Bandung: PT Remaja Rosdakarya.

Gunawan, H. 2014 Pendidikan Karakter, Bandung: Alfabert

Permendikbud No.63 Tahun 2014 'Pendidikan Kepramukaan Sebagai Kegiatan Ekstrakurikuler Wajib Pada Pendidikan Dasar dan Pendidikan Menengah'.

Rahmat, P.S. 2019. Perkembangan Peserta Didik. Jakarta Timur: PT Bumi Aksara 
Sugiyono. 2009. Metode Penelitian Kuantitatif Kualitatif dan $R \& D$. Bandung : Alfabeta.

Sukardi. 2016. Metodologi Penelitian Pendidikan: Kompetensi dan Praktiknya. Jakarta: Bumi Aksara.

Utomo, Jati. 2015. 'Pelaksanaan Ekstrakurikuler Pramuka di SD Negeri IV Wates'” Jurnal Pendidikan Guru Sekolah Dasar Edisi 2 Tahun ke IV Januari 2015

Woro, Sri dan Marzuki. 2016. "Peran Kegiatan Ekstrakulikuler Pramuka dalam Pembentukan Karakater Tanggung jawab Peserta Didik di SMP Negeri 2 Windusari Magelang”. Tesis Pascasarjana Universitas Negeri Yogyakarta. 